NBER WORKING PAPER SERIES

COMPOSITION OF INTERNATIONAL CAPITAL FLOWS:

A SURVEY

Koralai Kirabaeva

Assaf Razin

Working Paper 15599

http://www.nber.org/papers/w15599

\author{
NATIONAL BUREAU OF ECONOMIC RESEARCH \\ 1050 Massachusetts Avenue \\ Cambridge, MA 02138
}

December 2009

The views expressed herein are those of the author(s) and do not necessarily reflect the views of the National Bureau of Economic Research.

NBER working papers are circulated for discussion and comment purposes. They have not been peerreviewed or been subject to the review by the NBER Board of Directors that accompanies official NBER publications.

(C) 2009 by Koralai Kirabaeva and Assaf Razin. All rights reserved. Short sections of text, not to exceed two paragraphs, may be quoted without explicit permission provided that full credit, including $\odot$ notice, is given to the source. 
Composition of International Capital Flows: A Survey

Koralai Kirabaeva and Assaf Razin

NBER Working Paper No. 15599

December 2009

JEL No. F3

\begin{abstract}
In an integrated world capital market with perfect information, all forms of capital flows are indistinguishable. Information frictions and incomplete risk sharing are important elements that needed to differentiate between equity and debt flows, and between different types of equities. This survey put together models of debt, FDI, Fpi flows to help explain the composition of capital flows.

With information asymmetry between foreign and domestic investors, a country which finances its domestic investment through foreign debt or foreign equity portfolio issue, will inadequately augment its capital stock. Foreign direct investment flows, however, have the potential of generating an efficient level of domestic investment.

In the presence of asymmetric information between sellers and buyers in the capital market, foreign direct investment is associated with higher liquidation costs due to the adverse selection. Thus, the exposure to liquidity shocks determines the volume of foreign direct investment flows relative to portfolio investment flows. In particular, the information-liquidity trade-off helps explain the composition of equity flows between developed and emerging countries, as well as the patterns of FDI flows during financial crises.
\end{abstract}

The asymmetric information between domestic investors (as borrowers) and foreign investors (as lenders) with respect to investment allocation leads to moral hazard and thus generate an inadequate amount of borrowings. The moral hazard problem, coupled with limited enforcement, can explain why countries experience debt outflows in low income periods; in contrast to the predictions of the complete-market paradigm.

Finally, we analyze a risk-diversification model, where bond holdings hedge real exchange rate risks, while equities hedge non-financial income fluctuations. An equity home bias emerges as a calibratable equilibrium outcome.

Koralai Kirabaeva

Bank of Canada

Ottawa

Canada

kk329@cornell.edu

Assaf Razin

Department of Economics

Cornell University

Uris 422

Ithaca, NY 14853

and NBER

ar256@cornell.edu 


\title{
Composition of International Capital Flows: A Survey
}

\author{
Koralai Kirabaeva* and Assaf Razin ${ }^{\dagger}$
}

December 14, 2009

\section{Introduction}

The purpose of the survey is to elucidate some key mechanisms to explain the composition of capital flows among three major types: Foreign Direct Investments (FDI), Foreign Portfolio Investments (FPI) and debt. Flows that have equity-like features (that is, FDI and FPI) are presumed to be more stable and less prone to reversals. FDI yields more benefits than other types of financial flows because it comes with more direct control of management. ${ }^{1}$ Debt flows, consisting of bank loans and bonds, are regarded as more volatile than equities.

The models selected for the survey are evidently only a small subset of a wide range of models in the literature. Those surveyed capture, however, some unique and empiricallyrelevant features of key mechanisms through which financial and liquidity shocks drive major types of international capital flows. We choose to focus on only a few stylized models in order to offer the reader self-contained presentations.

\footnotetext{
${ }^{*}$ Bank of Canada

${ }^{\dagger}$ Cornell University and Tel Aviv University

${ }^{1}$ FDI is defined as investment with an equity stake of $10 \%$ or more, according to the international accounting standards.
} 


\section{Pecking order of capital flows: Information Asymmetry between Domestic and Foreign Investors}

There is strong evidence about home-court advantage in international portfolio investment. One explanation is an information asymmetry between domestic and foreign investors about the performance of domestic firms. The information asymmetry can cause an aggregate production inefficiency and lead to the foreign underinvestment and domestic oversaving. As a result, the marginal productivity of capital at home is high relative to the home country marginal cost of importing capital.

Empirical studies by Portes, Rey and Oh [34], and Loungani, Mody and Razin [30] suggests that informational asymmetries significantly contribute to the negative relationship between asset trade and distance. The gravity models predict that bilateral international transactions are positively related to the size of two economies and negatively to the distance between them. Distance is measured as a proxy for informational frictions, transaction and transportation costs.

In Froot and Stein [18], Klein and Rosengren [25], Klein, Peek, and Rosengren [24], the hypothesis is that FDI is information intensive, and thus FDI investors, who know more about their investments than outsiders, face a problem in raising resources for their investments. Gordon and Bovenberg [21] assume asymmetric information between domestic investors and foreign investors to explain the home bias phenomenon. Razin and Sadka [35] analyze the gains from FDI when foreign direct investors have superior information on the fundamentals of their investment, relative to foreign portfolio investors.

Razin, Sadka and Yuen [36] explored the pecking order among the three types of capital flows: debt, equity, and FDI in the context of a model in which domestic savers and FDI investors are endowed with better information than the portfolio foreign investors. The ranking of capital inflows is somewhat similar to the pecking order' of corporate capital structure. Recall that in corporate finance the hypothesis maintains that the firms prefer internal finance (retained earnings, the analogue of FDI in the case of international flows) to external finance. If the latter is required, then firms will issue the safest security (the analogue of debt flows), and they will issue new equity (the analogue of equity portfolio 
flows) only as a last resort.

\subsection{Razin, Sadka, and Yuen (1999) model}

Consider a small, capital-importing country referred as a home country. There are $N$ exante risk-neutral identical domestic firms. There are two time periods. Each firm chooses capital input $K$ in the first period. In the second period, the output is equal to $F(K)(1+\varepsilon)$, where $F(\cdot)$ is a production function exhibiting diminishing marginal productivity of capital and $\varepsilon$ is a random productivity factor. The productivity factor $\varepsilon$ is independent across firms, it has zero mean and bounded below by -1 . The cumulative distribution function of the productivity shock $\varepsilon$ is $\Phi(\cdot)$. The domestic interest rate is denoted by $r$ and foreign by $r^{*}$.

\subsubsection{Foreign Debt Investment}

Investment decisions are made by firms before $\varepsilon$ is observed. Then they issue debt.

Given its investment decision $(K)$, a firm may choose to default on its debt if $F(K)(1+\varepsilon)$ is smaller than $K(1+r)$. Therefore, firms with productivity $\varepsilon>\varepsilon_{0}$ will fully repay their non-recourse loans, where $\varepsilon_{0}$ is a threshold level of $\varepsilon$, such that $F(K)\left(1+\varepsilon_{0}\right)=K(1+r)$. So, the fraction of solvent firms is $N\left(1-\Phi\left(\varepsilon_{0}\right)\right)$.

The domestic firms are better informed than the foreign lenders, they are able to observe productivity $\varepsilon$ before making their loan decisions. Domestic lenders will extend loans only to firms with productivity $\varepsilon>\varepsilon_{0}$. The foreign lenders will advance loans to all firms since they don't observe $\varepsilon$. Denote the fraction of solvent firms financed by foreign lenders by $\beta$. Therefore, the expected payoff of foreign lenders is given by

$$
\text { Payoff } \equiv \beta N\left(1-\Phi\left(\varepsilon_{0}\right)\right) K(1+r)+N \Phi\left(\varepsilon_{0}\right) F(K)\left(1+e^{-}\right)
$$

where $e^{-} \equiv E\left[\varepsilon \mid \varepsilon \leq \varepsilon_{0}\right]$. The amount of loans given by foreign lenders is given by Loan $\equiv\left(\beta N\left(1-\Phi\left(\varepsilon_{0}\right)\right)+N \Phi\left(\varepsilon_{0}\right)\right) K$.

The expected value of the representative firm

$$
V \equiv F(K)-\left[\left(1-\Phi\left(\varepsilon_{0}\right)\right) K(1+r)+\Phi\left(\varepsilon_{0}\right) F(K)\left(1+e^{-}\right)\right]
$$


The value maximizing level of $K$ is such that

$$
F^{\prime}(K)=\frac{\left(1-\Phi\left(\varepsilon_{0}\right)\right) K(1+r)}{1-\Phi\left(\varepsilon_{0}\right)\left(1+e^{-}\right)}
$$

which implies that due to the possibility of default,

$$
F^{\prime}(K)<1+r
$$

This inequality represents the oversaving inefficiency: domestic stock of capital is larger than what domestic savers are willing to pay for in terms of foregone present consumption.

The expected payoff of foreign lender should be equal to the capital income on Loan, which implies that $r^{*}<r$ and

$$
F^{\prime}(K)>1+r^{*}
$$

This means that aggregate production is inefficient and the country can gain from the debt-financed increase in the stock of domestic capital. Although debt instruments specify that the issuer of these instruments must pay a fixed value, in the case of default the lender becomes an equity holder. Thus inefficient foreign financing also applies to foreign portfolio investment, as illustrated in the next subsection.

\subsubsection{Foreign Portfolio Investment}

As before, all firms choose investment level $K$ in the first period before the random productivity factor $\varepsilon$ is observed. All firms are originally owned by domestic investors who equity finance their capital investment. Foreign investors do not observe the productivity $\varepsilon$ when they purchase shares in existing firms. Therefore, they offer the same price for all firms, reflecting the average productivity. As a result, there is a threshold level of productivity $\varepsilon_{0}$ such that firms with productivity above $\varepsilon_{0}$ will not be willing to sell at that price.

The value of the representative firm is equal to $F(K)(1+\varepsilon)$. Thus the threshold productivity $\varepsilon_{0}$ is defined by

$$
\frac{F(K)\left(1+e^{-}\right)}{\left(1+r^{*}\right)}=\frac{F(K)\left(1+\varepsilon_{0}\right)}{(1+r)}
$$

where $r^{*}<r$ so that foreigners have a positive holdings in domestic firms. 
Then, the amount of foreign portfolio investment is given by

$$
F P I=\frac{N \Phi\left(\varepsilon_{0}\right) F(K)\left(1+e^{-}\right)}{\left(1+r^{*}\right)} .
$$

The firm's expected market value net of the original capital investment is

$$
V=\Phi\left(\varepsilon_{0}\right) \frac{F(K)\left(1+e^{-}\right)}{\left(1+r^{*}\right)}+\left(1-\Phi\left(\varepsilon_{0}\right)\right) \frac{F(K)\left(1+e^{+}\right)}{(1+r)}-K
$$

Maximizing this expression with respect to $K$ yields the following condition:

$$
\Phi\left(\varepsilon_{0}\right) \frac{F^{\prime}(K)\left(1+e^{-}\right)}{\left(1+r^{*}\right)}+\left(1-\Phi\left(\varepsilon_{0}\right)\right) \frac{F^{\prime}(K)\left(1+e^{+}\right)}{(1+r)}-1=0 .
$$

Because the firm knows, when making its capital investment decision, that it will be sold at a premium if faced with low-productivity events, it tends to overinvest relative to the rate of return to domestic investors and underinvest relative to the rate of return to foreign investors,

$$
\left(1+r^{*}\right)<F^{\prime}(K)<(1+r)
$$

As in the case with debt flows, the information asymmetry between domestic and foreign investors creates inefficiencies, such as oversaving by domestic investors and underinvestment by foreigners, that reduce the gains from international capital flows.

\subsubsection{Foreign Direct Investment}

The foreign direct investor buy a domestic firm before investment decision is made. So, the foreign investors and direct investors are equally informed. The capital $K^{*}$ is imported from the foreign country, and the output is $F\left(K^{*}\right)(1+\varepsilon) . J$ is a number of firms bought by foreign investors. The market value of the firm sold to foreign direct investors is

$$
V^{*}=\frac{F\left(K^{*}\right)}{\left(1+r^{*}\right)}-K^{*}
$$

Therefore, the amount of foreign direct investment is given by

$$
F D I=J\left(K^{*}+V^{*}\right)
$$

In an equilibrium with positive number of firms owned by both domestic and foreign investors, $V^{*}=V$, where $V=\frac{F(K)}{(1+r)}-K$. 
The optimal level of capital investment $K^{*}$ and $K$ should satisfy

$$
\begin{aligned}
F^{\prime}\left(K^{*}\right) & =1+r^{*} \\
F^{\prime}(K) & =1+r .
\end{aligned}
$$

When FDI investors have access to the domestic debt market: $r=r^{*}$, then we get $F^{\prime}\left(K^{*}\right)=\left(1+r^{*}\right)=F^{\prime}(K)=1+r$. That is, global capital markets are efficient. In case of FDI, the asymmetric information problems are alleviated due to the actual exercise of management and control.

\section{Composition of Equity Flows: Asymmetric Information and Liquidity}

An empirical regularity is that the share of FDI in total foreign equity flows is larger for developing countries than for developed countries. Regarding the second moments of foreign equity flows, it is known that the volatility of FDI net inflows is, in general, much smaller than that of FPI net inflows. Moreover, empirical analysis has established that the differences in volatility between FPI and FDI flows are much smaller for developed economies than for developing economies.

Rossi and Volpin [38] find that the volume of M\&A activity is significantly larger in countries with better corporate governance standards and stronger investor protection. Albuquerque [3] argues that financially constrained countries borrow more through FDI because FDI is harder to expropriate. Albuquerque, Loayza, and Serven [4] analyze the dynamic of FDI in response to increase integration of capital markets. They find that financial integration increases the relative importance of global factors as drivers of foreign investment. Furthermore, developing countries' exposure to global factors has increased faster than that of developed countries.

Goldstein and Razin [19] focus on information-liquidity trade-off of FDI relative to FPI. FDI investors are in effect the managers of the firms under their control; whereas FPI investors effectively delegate decisions to managers. Consequently, direct investors are more 
informed than portfolio investors regarding the prospects of their projects. This information enables direct investors to manage their projects more efficiently. ${ }^{2}$ This informational advantage, however, comes at a cost. If investors need to sell their investments before maturity because of liquidity shocks, the price they can get will be typically lower when buyers know that they have more information on the fundamentals of the investment project. A key implication of the model is that the choice between FDI and FPI will be linked to the likelihood with which investors expect to get a liquidity shock.

\subsection{Goldstein and Razin (2006) model}

Consider a small economy is faced by a continuum $[0,1]$ of foreign investors. Each foreign investor has an opportunity to invest in one investment project. Foreign investment can occur in one of two forms: either as a direct investment or as a portfolio investment. A direct investor effectively acts like a manager, whereas in case of a portfolio investment, the project is managed by an outsider.

There are three periods of time: 0,1 , and 2 . In period 0 , each investor decides whether to make a direct investment or a portfolio investment. In period 2 , the project matures. The net cash flow from the project is given by

$$
R(K, \varepsilon)=(1+\varepsilon) K-\frac{1}{2} A K^{2}
$$

where $\varepsilon$ is an idiosyncratic random productivity factor, which is independently realized for each project in period 1 , and $K$ is the level of capital input invested in the project in period 1, after the realization of $\varepsilon$. The parameter $A$ reflects production costs. The productivity shock $\varepsilon$ is distributed between -1 and 1 with mean 0 with the cumulative distribution function $\Phi(\cdot)$, and the density function is $f(\cdot)=\Phi^{\prime}(\cdot)$. Investors choose the form of investment that maximizes (ex-ante) expected payoff.

In period 1, after the realization of the productivity shock, the manager of the project observes $\varepsilon$. Thus, if the investor owns the project as a direct investment, she observes $\varepsilon$, and chooses $K$, so as to maximize the net cash flow: $K^{d}(\varepsilon)=\frac{1+\varepsilon}{A}$.

\footnotetext{
${ }^{2}$ The idea that control increases efficiency and value of the firm is supported empirically by recent papers in the international finance literature (Perez-Gonzalez (2005) and Chari, et al. (2005)).
} 
Therefore, the ex-ante expected net cash flow from a direct investment, if held until maturity, is:

$$
E V_{D}=\frac{E\left((1+\varepsilon)^{2}\right)}{2 A} .
$$

In case of a portfolio investment, the owner is at arms length relationships with the manager, and thus she cannot observe $\varepsilon$. In this case, the owner maximizes the expected return absent any information on the realization of $\varepsilon$, and is based on the ex-ante 0 mean. Thus, the manager will be instructed to choose $K^{p}=K^{d}(0)=\frac{1}{A}$. Then, the ex-ante expected payoff from a portfolio investment, if held until maturity, is:

$$
E V_{P}=\frac{1}{2 A}
$$

Comparing (15) with (16), we see that if the project is held until maturity, it yields a higher payoff as a direct investment than as a portfolio investment. This reflects the efficiency that results from a hands-on management style in the case of a direct investment.

There are also costs for FDI investment, however. First, an FDI investor has to incur a fixed cost in order to acquire the expertise to manage the project directly. We denote this cost, which is exogenously given in the model, by $C$. Second, there is an endogenous cost arising from the possibility of liquidity shocks occurring in period 1 . There is a discount when selling a project managed as direct investment due to information asymmetries, as demonstrated below.

In period 1, before the value of $\varepsilon$ is observed, the owner of the project might get a liquidity shock. With the realization of a liquidity shock, the investor is forced to sell the project in period 1. This feature of the model is similar to the preference-shock assumption made by Diamond and Dybvig [14]: an investor who is subject to a liquidity shock derives her utility only from period-one consumption. If, however, she is not subject to a liquidity shock, she derives her utility from period-two consumption. We denote by $\lambda$ the probability of a liquidity shock. We assume that there are two types of foreign investors. In particular, half of the investors will need to sell with probability $\lambda_{H}$ and half with probability $\lambda_{L}$ such that $1>\lambda_{H}>\frac{1}{2}>\lambda_{L}>0$, and $\lambda_{H}+\lambda_{L}=1$. Investors know ex ante whether they are of a $\lambda_{H}$ type or a $\lambda_{L}$ type and this is their private information. In addition to liquidity-based sales, there is a possibility that an investor will liquidate a project in period 1 if she observes 
a low realization of $\varepsilon$. Then the price that buyers are willing to pay for a direct investment that is being sold in period 1 is:

$$
P_{D}=\frac{1}{2 A} \frac{\left(1-\lambda_{D}\right) \int_{-1}^{\varepsilon_{D}}(1+\varepsilon)^{2} f(\varepsilon) d \varepsilon+\lambda_{D}}{\left(1-\lambda_{D}\right) \Phi\left(\underline{\varepsilon}_{D}\right)+\lambda_{D}} .
$$

Here, $\underline{\varepsilon}_{D}$ is a threshold level of $\varepsilon$, set by the direct investor; below which the direct investor is selling the project without being forced to do so by a liquidity shock; $\lambda_{D}$ is the probability, as perceived by the market, that an FDI investor gets a liquidity shock. In (17), it is assumed that if the project is sold due to a liquidity shock, that is, before the initial owner observes $\varepsilon$, the value of $\varepsilon$ is not recorded in the firms before the sale. Therefore, the buyer does not know the value of $\varepsilon$. However, if the project is sold for lowprofitability reasons, the owner will know the value of $\varepsilon$ after the sale. The threshold $\underline{\varepsilon}_{D}$ is determined in equilibrium. The initial owner sets the threshold level $\underline{\varepsilon}_{D}$, such that given $P_{D}$, when observing $\underline{\varepsilon}_{D}$, an investor is indifferent between selling and not selling the project in absence of a liquidity shock. Thus:

$$
P_{D}=\frac{\left(1+\underline{\varepsilon}_{D}\right)^{2}}{2 A}
$$

Equations (17) and (18) together determine $P_{D}$ and $\underline{\varepsilon}_{D}$ as functions of the market-perceived probability of sale due to the liquidity shock $\left(\lambda_{D}\right)$. We denote these functions as: $\varepsilon_{D}\left(\lambda_{D}\right)$ and $P_{D}\left(\lambda_{D}\right)$.

A portfolio investor sells the projects in period 1, everybody knows she does it because of a liquidity shock. Thus, the price of the project is given by

$$
P_{P}=\frac{1}{2 A} \text {. }
$$

Comparing the price of FDI, which is determined by (17) and (18), with the price of FPI, which is determined by (19), we see that the resale price of a direct investment in period 1 is always lower than the resale price of a portfolio investment in that period. The intuition is that if a direct investor prematurely sells the investment project, the market price must reflect the possibility that the sale originates from inside information on low prospects of this investment project. This constitutes the second (liquidity) cost of FDI. 
Based on this analysis, we can write the ex-ante expected net cash flow from FDI:

$$
E V_{D}\left(\lambda_{i}, \lambda_{D}, A, C\right)=\left[\left(1-\lambda_{i}\right)\left(\begin{array}{c}
\frac{\left(1+\underline{\varepsilon}_{D}\left(\lambda_{D}\right)\right)^{2}}{2 A} \Phi\left(\underline{\varepsilon}_{D}\left(\lambda_{D}\right)\right) \\
+\int_{\underline{\varepsilon}_{D}\left(\lambda_{D}\right)}^{1} \frac{(1+\varepsilon)^{2}}{2 A} f(\varepsilon) d \varepsilon
\end{array}\right)+\lambda_{i} \frac{\left(1+\underline{\varepsilon}_{D}\left(\lambda_{D}\right)\right)^{2}}{2 A}\right]-C .
$$

The ex-ante expected net cash flow from FPI is simply:

$$
E V_{P}(A)=\frac{1}{2 A}
$$

Then, the difference between the expected value of FDI and the expected value of FPI is:

$$
\operatorname{Diff}\left(\lambda_{i}, \lambda_{D}, A, C\right) \equiv E V_{D}\left(\lambda_{i}, \lambda_{D}, A, C\right)-E V_{P}(A)
$$

Clearly, investor will choose FDI (FPI) when $\operatorname{Diff}\left(\lambda_{i}, \lambda_{D}, A, C\right)>0(<0)$ and will be indifferent between the two (that is, may choose either FDI or FPI) when Diff $\left(\lambda_{i}, \lambda_{D}, A, C\right)=$ 0 .

To complete the description of equilibrium, it remains to specify how $\lambda_{D}$, the market perceived probability that an FDI investor will get a liquidity shock. Assuming that rational expectations hold in equilibrium, $\lambda_{D}$ has to be consistent with the equilibrium choice of the two types of investors between FDI and FPI, such that

$$
\lambda_{D}=\frac{\lambda_{H} \lambda_{H, F D I}+\lambda_{L} \lambda_{L, F D I}}{\lambda_{H, F D I}+\lambda_{L, F D I}}
$$

where $\lambda_{H, F D I}$ is the proportion of $\lambda_{H}$ investors who choose FDI in equilibrium and $\lambda_{L, F D I}$ is the proportion of $\lambda_{L}$ investors who choose FDI in equilibrium.

There are five possible cases that can potentially be observed in equilibrium. Case 1: All investors choose FDI. Case 2: $\lambda_{L}$ investors choose FDI; $\lambda_{H}$ investors split between FDI and FPI. Case 3: $\lambda_{L}$ investors choose FDI; $\lambda_{H}$ investors choose FPI. Case $4: \lambda_{L}$ investors split between FDI and FPI; $\lambda_{H}$ investors choose FPI. Case 5: All investors choose FPI. Equilibrium outcomes depend on production cost $A$, and liquidity preferences $\left(\lambda_{L}, \lambda_{H}\right)$. As the production cost $A$ increases, we are more likely to observe FPI and less likely to observe FDI in equilibrium. As the difference in liquidity needs between the two types of investors increase, we are more likely to see a separating equilibrium, where different types of investors choose different forms of investment. 
Suppose now that an aggregate liquidity shock occurs in period one with probability $q$. Conditional on the realization of the aggregate liquidity shock, individual investors have to sell their investment at period one with probabilities $\lambda_{L}$ and $\lambda_{H}$. This implies that as the probability of an aggregate liquidity shock $q$ increases, there will be more FPI and less FDI in equilibrium. Thus, the ratio of FPI to FDI will increase. The intuition is that as the probability of an aggregate liquidity shock increases, agents know that they are more likely to sell the investment early, in which case they will get a low price since buyers do not know whether they sell because of an individual liquidity need or because of adverse information on the productivity of the investment. As a result, the attractiveness of FDI decreases.

The empirical prediction is that countries with a higher tendency for liquidity problems will be source of a higher ratio of FPI to FDI. Goldstein, Razin, and Tong [20] find empirical evidence that a higher probability of a liquidity crisis in the source country has a significant positive effect on the ratio between FPI and FDI.

\section{Equity Flows and Financial Crises: Asymmetric Informa- tion and Liquidity}

Emerging economies have counter-cyclical current accounts, they experience large capital outflows during crises. The theoretical literature argues that financial crises lead to an exit of foreign investors even if there are no shocks to fundamentals. The following papers link financial crises and liquidity through models of self-fulfilling investors' run. Chang and Velasco [10] place international illiquidity at the center of financial crises. They argue that a small shock may result in financial distress, leading to costly asset liquidation, liquidity crunch, and large drop in asset prices. Caballero and Krishnamurthy [9] argue that during a crisis self-fulfilling fears of insufficient collateral may trigger a capital outflow.

However, financial crises may be associated with an outflow of FPI and a simultaneous inflow of FDI. This behavior reflects the fire-sale FDI phenomenon when domestic companies and assets are acquired by foreign investors at fire-sale prices. Krugman [27] notes that the Asian financial crisis has been accompanied by a wave of inward direct investment. Furthermore, Aguiar and Gopinath [2] analyze data on mergers and acquisitions in East 
Asia between 1996 and 1998 and find that the liquidity crisis is associated with an inflow of FDI. Moreover, Acharya, Shin, and Yorulmazer [1] observe that FDI inflows during financial crises are associated with acquisitions of controlling stakes. Baker, Foley, and Wurgler [7] argue that FDI flows may also reflect arbitrage activity by multinationals as well as the purchase of undervalued host country assets.

Kirabaeva [23] analyzes the composition of investment (direct vs portfolio) across two countries in the presence of heterogeneity in liquidity risk and asymmetric information about the investment productivity. During liquidity crises (increase in liquidity preferences) level of FDI may increase or decrease depending on the equilibrium. The dual effect of an increase in the liquidity risk on the capital flows corresponds to the empirically observed pattern of FDI during liquidity crises. ${ }^{3}$ The model offers an alternative explanation of the fire-sale FDI phenomenon based on the adverse selection. At the same time, it provides a possibility of a decrease in FDI through self-fulfilling expectations.

\subsection{Kirabaeva (2009) model}

There is a continuum of agents with an aggregate Lebesgue measure of unity. There are 3 time periods: $t=0,1,2$. There is only one good in the economy, and in period zero, all agents are endowed with one unit of good that can be consumed and invested. Agents consume in period 1 or 2 , depending on whether they receive a liquidity shock in period 1. The probability of receiving a liquidity shock in period one is country-specific: investors in each country $k \in\{A, B\}$ have the same probability $\lambda_{k}$. This probability $\left(\lambda_{k}\right)$ captures the investor's exposure to the liquidity risk in a given country ${ }^{4}$. Investors who receive a

\footnotetext{
${ }^{3}$ Financial crises may be associated with an outflow of FPI and a simultaneous inflow of FDI, e.g., the 1994 crisis in Mexico and the late 1990s crisis in South Korea. However, there is also evidence that some crises have been accompanied by an outflow foreign investment, including FDI, e.g., the 2001 crisis in Argentina and 1990s crisis in Indonesia.

${ }^{4}$ There are two possible interpretations of the liquidity risk. One is the probability of a liquidity crisis that is unrelated to fundamentals of the economy. In fact, recent financial crises exhibit a large liquidity run component while the underlying macro fundamentals are not necessarily weak. Another interpretation is a measure of financial market development. In more developed financial (credit) markets it is easier for agents to borrow in case of liquidity needs, and therefore the probability of investment liquidation is smaller, whereas in developing and emerging countries access to the world capital markets is limited. So a country
} 
liquidity shock have to liquidate their risky long-term asset holdings and consume all their wealth in period one. So they are effectively early consumers who value consumption only at date $t=1$. The rest are the late consumers who value the consumption only at date $t=2$. Since there is no aggregate uncertainty, $\lambda_{k}$ is also a fraction of investors hit by a liquidity shock in country $k$.

Investors from country $k$ have Diamond-Dybvig type of preferences:

$$
U_{k}\left(c_{1}, c_{2}\right)=\lambda_{k} u\left(c_{1}\right)+\left(1-\lambda_{k}\right) u\left(c_{2}\right)
$$

where $c_{t}$ is the consumption at dates $t=1,2$. In each period, investors have mean-variance utility

$$
E\left[u\left(c_{t}\right)\right]=E\left[c_{t}\right]-\frac{\gamma}{2} \operatorname{Var}\left[c_{t}\right]
$$

with $\gamma$ representing the degree of risk aversion.

There are two types of constant returns technology. One is a storage technology (safe asset), which has zero net return. The safe asset is the same in both countries. The other type of technology is a long-term risky investment project (risky asset). In period two, a risky investment project has a random payoff $\widetilde{R}$ per unit of investment which represents idiosyncratic investment productivity. It yields nothing at date $t=1$. There is a continuum of investment projects available in each country. The investment productivity realizations are independent across projects and across countries. The investment productivity of each project $\widetilde{R}_{k}^{i}$ in country $k \in\{A, B\}$ is a independent realization of normal distribution $N\left(R_{k}, \sigma_{k}^{2}\right)$ with mean $R_{k}$ and variance $\sigma_{k}^{2} .{ }^{5}$ The productivity mean $R_{k}$ is a random variable that takes two values: a low value $R_{k l}$ with probability $\pi_{k}$ and a high value $R_{k h}$ with probability $\left(1-\pi_{k}\right)^{6}$. For each investment project in country $k$, nature picks the mean $R_{k}$ where $R_{k} \in\left\{R_{k l}, R_{k h}\right\}{ }^{7}$ The expected productivity mean is denoted by with a low liquidity risk can be viewed as a developed economy, and a country with a high liquidity risk can be viewed as a developing or emerging economy.

${ }^{5}$ More precisely, all portfolio investments have the same productivity mean $\bar{R}_{p k}$, and all direct investments have the same productivity mean $\bar{R}_{d k}>\bar{R}_{p k}$.

${ }^{6}$ In addition, the probability $\pi_{k}$ of investment project to be less productive depends on the type of ownership: the direct investment is less likely to have low mean productivity than the portfolio investment, i.e., $\pi_{d k}<\pi_{p k}$.

${ }^{7}$ Direct investors are able to observe the true distribution, portfolio investors use the unconditional 
$\bar{R}_{k}=\pi_{k} R_{k l}+\left(1-\pi_{k}\right) R_{k h}$ with $\bar{R}_{k}>1$. All parameters of the productivity distribution are country-specific, with $\bar{R}_{k}$ representing the expected profitability of investment project and $\sigma_{k}^{2}$ capturing the investment risk in country $k{ }^{8}$

The characteristic features of direct investment are higher profitability and access to private information about investment productivity $\left(R_{k}\right)$. Portfolio investment represents holdings of assets which allow for risk diversification (investing into multiple projects) and greater liquidity. Taking advantage of the inside information, direct investors may sell lowproductive investments and keep the high-productive ones under their ownership. This generates a "lemons" ${ }^{9}$ problem: the buyers do not know whether the investment is sold because of its low productivity or due to an exogenous liquidity shock. Therefore, due to this information asymmetry, there is a discount on the prematurely sold direct investment (relative to the prematurely sold portfolio investment).

In period zero, investors choose how much to invest into risky long-term projects in each of the two countries, as well as the ownership type for each project (direct or portfolio). In period one, idiosyncratic liquidity shocks are realized and, subsequently, risky investments are traded in the financial market. The late consumers are the buyers in the financial market. All investment projects pay off in the second period. This "cash-in-the-market" framework $^{10}$ allows one to capture the effect of market liquidity (demand for risky investments in the interim period) on the investment choice. The equilibrium prices of direct and portfolio investments depend not only on their expected payoffs but also on investors' liquidity preferences and uncertainty about the investment productivity. If market is more liquid then expected gains from trading on private information are larger, since it is easier for informed traders to hide behind the liquidity traders. Therefore, in a more liquid market direct investors have higher profits from selling on private information. On the other hand, a larger fraction of direct investors leads to a less liquid market.

There are two types of equilibria. In the first type, only investors from the country with distribution which the mixture of two normal distributions.

${ }^{8}$ In addition to a lower liquidity risk, a developed country can be characterized by a higher expected profitability (adjusted for risk) and less asymmetric information about the productivity.

${ }^{9}$ Akerlof (1970)

${ }^{10}$ Allen and Gale [5] 
a lower liquidity risk choose to hold direct investment. In the second type, investors from both countries hold direct investments. In this case, there are strategic complementarities in choosing direct investment. This generates a possibility of multiple equilibria through the self-fulfilling expectations. If countries have the same fundamentals, the country with a higher liquidity risk attracts less inward foreign investment, but a larger share of it is in the form of FDI. Also, the country with a higher level of asymmetric information about investment productivity attracts more FDI relative to FPI since the marginal benefits from private information are larger.

These results are consistent with the empirical findings that countries that are less financially developed and have weaker financial institutions tend to attract more capital in the form of FDI. Furthermore, it can explain the phenomenon of bilateral FDI flows among developed countries, and one-way FDI flows from developed to emerging countries.

Consider the effect of an increase in the liquidity risk $\left(\lambda_{k}\right)$ on the composition of foreign investment. Such an increase results in the drying up of market liquidity as more investors have to sell their risky asset holdings. At the same time, it becomes more likely that if a direct investment is sold before maturity, it is sold due to exogenous liquidity needs rather than an adverse signal about investment productivity. This reduces the adverse selection problem and therefore results in a smaller information discount on prematurely sold direct investments. This effect captures the phenomenon of fire-sale FDI during liquidity crises. If economy is in the unique equilibrium then higher liquidity risk leads to a higher level of FDI. However, if there are multiple equilibria then FDI may decline as the liquidity risk becomes higher. In this case, an outflow of FDI is induced by self-fulfilling expectations.

\section{International Lending: Moral Hazard and Limited En- forcement}

\subsection{Debt Flows}

Debt flows remain the dominant form of flows to developing economies, although their relative importance has declined over time. The empirical literature on financial globalization 
documents a systematic empirical link between exposure to debt flows and the likelihood and severity of financial crises. Rodrik and Velasco [37] find that countries with a larger short-term debt stock than reserves are more likely to experience a financial flows reversal. Tong and Wei [39] find that a large pre-crisis exposure to non-FDI capital inflows tends to be associated with a more severe credit crunch during the crisis. However, debt flows can be beneficial in certain circumstances. A country that has no access to equity or FDI inflows, might still be able to benefit from debt inflows to finance illiquid investments (Diamond and Rajan [15]). ${ }^{11}$

Wei [42] argues that sudden reversals of capital flows are more likely to occur among countries that rely relatively more on portfolio debt flows, including bank loans, and less on FDI. Moreover, short-term bank loans to developing countries tend to increase during booms and rapidly decrease during economic slowdowns. Claessens, Dooley and Warner [11] find that long-term debt flows are often as volatile as short-term flows. The procyclicality and high volatility of debt flows can lead to inefficient capital allocation and generate moral hazard. McKinnon and Pill [31] show financial liberalization without adequate supervision can result in overborrowing by banks. Furthermore, banks may expose their balance sheets to currency risk if taking speculative open positions in foreign exchange are permitted.

\subsection{Lending with Moral Hazard and Limited Enforcement}

With access to complete international credit markets, the economy would be able to borrow to finance a stable level of consumption and investment. However, empirical findings suggest that countries often experience capital outflows in the very low income periods.

Eaton and Gersovitz [16] analyze a model with incomplete international credit market and risk of repudiation. The level of debt is the minimum of the credit demands of the economy and the credit constraints by lenders. Borrowing occurs in period or relatively low income and must be fully repaid in the succeeding period. Failure to repay prevents borrowing in the subsequent period. Atkeson [6] studies a model of lending that contains both a moral hazard problem and an enforcement problem. The introduction of moral

\footnotetext{
${ }^{11}$ See Kose, Prasad, Rogoff, and Wei [26] for a survey of the literature on the volatility and risk of debt flows.
} 
hazard due to asymmetric information between borrower and lender, allows to explain why the occurrence of especially low output realizations prompt international lenders to ask these countries for repayments. Tsyrennikov [40] shows that the capital outflows in the lowest output state in a model with only moral hazard can be quantitatively significant and larger than in a model which also includes limited enforcement.

\subsubsection{Atkeson (1991) model}

A risk-averse borrower lives for $t=0,1,2, \ldots$ At period 0 , he is endowed with $Q_{o}$ units of good, and in each period the borrower has access to the investment technology: $Y_{t+1}=$ $f\left(I_{t}, \varepsilon_{t+1}\right)$ where $I_{t}$ are units of goods invested and $\varepsilon_{t+1}$ is i.i.d. random variable. The probability density of $Y_{t+1}$ conditioned on $\mathrm{I}_{t}$ is $g\left(Y_{t+1}, I_{t}\right) .{ }^{12}$ The borrowers preferences are represented by

$$
(1-\delta) E_{o} \sum_{t=0}^{\infty} \delta^{t} u\left(c_{t}\right)
$$

.where $\beta \in(0,1), u^{\prime}(c)>0, u^{\prime \prime}(c)<0$.

In the autarky environment with no access to the international credit market, the optimal value function $V_{a u t}(Q)$ satisfies the following Bellman equation:

$$
V_{a u t}(Q)=\max _{I \in[0, Q]}\left\{(1-\delta) u(Q-I)+\delta \sum_{Q^{\prime}} V_{a u t}\left(Q^{\prime}\right) g\left(Q^{\prime}, I\right)\right\} .
$$

Complete credit market The risk-neutral lender can observe the borrower's investment choice, and there is complete enforcement. The borrower can issue Arrow securities that pay out $d_{i}$ in state $i$ and $q\left(Y_{i}, I\right)$ is the price of such security given last period investment $I$. Since lender is risk-neutral, the Arrow securities are priced such that $q\left(Y_{i}, I\right)=\delta g\left(Y_{i}, I\right)$.

The optimal value function $V_{\text {compl }}(Q)$ satisfies the Bellman equation:

$$
V_{\text {compl }}(Q)=\max _{I \in[0, Q]}\left\{\begin{array}{c}
(1-\delta) u(c)+\delta \sum_{Y^{\prime}} V_{A D}\left(Y^{\prime}-d\left(Y^{\prime}\right)\right) g\left(Y^{\prime}, I^{*}\right) \\
+\mu\left(Q-c+\sum_{Y^{\prime}} q\left(Y^{\prime}, I^{*}\right) d\left(Y^{\prime}\right)-I^{*}\right)
\end{array}\right\},
$$

\footnotetext{
${ }^{12}$ Several assumptions are imposed on $\mathrm{g}(\mathrm{Y}, \mathrm{I})$ to make the model tractable.
} 
where $I^{*}$ is the optimal investment level such that it maximizes the project present value evaluated at the Arrow securities prices

$$
\max _{I \geq 0}\left\{-I+\delta \sum_{Y^{\prime}} Y^{\prime} g\left(Y^{\prime}, I\right)\right\} .
$$

The borrower borrows a constant amount $\sum_{Y^{\prime}} q\left(Y^{\prime}, I^{*}\right) d\left(Y^{\prime}\right)$ and invests $I^{*}$ each period, and makes high repayment when $Y^{\prime}$ is high and low repayment when $Y^{\prime}$ is low. This is a full-insurance solution.

Moral Hazard and Limited Enforcement Next consider the environment with moral hazard: the lender cannot observe the investment choice $I_{t}$ which affects the probability distribution of returns $Y$; and limited enforcement: the borrower can default on the promised repayment.

The risk-neutral lender lives for two-periods and is endowed with $M$ units of good in each period. He is willing to lend or borrow at the risk-free rate $1 / \delta$. The lender observes $Q$ but does not observe $I$ or $c$. The optimal recursive contract takes the following form:

$$
\begin{aligned}
d_{t+1} & =d\left(Y_{t+1}, Q_{t}\right) \\
Q_{t+1} & =Y_{t+1}-d_{t+1} \\
b_{t} & =b\left(Q_{t+1}\right) \\
c_{t}+I_{t}-b_{t} & =Q_{t} .
\end{aligned}
$$

The value function $V_{A t k}(Q)$ satisfy the following Bellman equation:

$$
\begin{array}{ll}
V_{A t k}(Q)= & \max _{A}\left\{(1-\delta) u(c)+\delta \sum_{Y^{\prime}} V_{A t k}\left(Y^{\prime}-d\left(Y^{\prime}, Q\right)\right) g\left(Y^{\prime}, I\right)\right\} \\
\text { s.t } \quad & \text { (i) } \quad c+I-b \leq Q, b \leq M,-d\left(Y^{\prime}, Q\right) \leq M, c \geq 0, I \geq 0 \\
& \text { (ii) } \quad b \leq \delta \sum_{Y^{\prime}} d\left(Y^{\prime}, Q\right) g\left(Y^{\prime}, I\right) \\
& \text { (iii) } \quad V_{A t k}\left[Y^{\prime}-d\left(Y^{\prime}\right)\right] \geq U\left(Y^{\prime}\right) \\
& \text { (iv) } \quad I=\arg \max \left\{(1-\delta) u(Q+b-I)+\delta \sum_{Y^{\prime}} V_{A t k}\left(Y^{\prime}-d\left(Y^{\prime}, Q\right)\right) g\left(Y^{\prime}, I\right)\right\}
\end{array}
$$


The optimal contract can be constructed by iterating to convergence on constraint conditions.

The capital outflow in states with low output is characterized by the following conditions: the optimality condition

$$
V_{A t k}(Q)=\max _{I \in[0, Q+b]}\left\{u(Q+b-I)+\delta \sum_{Y^{\prime}} V_{A t k}\left(Y^{\prime}-d\left(Y^{\prime}, Q\right)\right) g\left(Y^{\prime}, I\right)\right\},
$$

and the participation constraint

$$
V_{\text {Atk }}(Q) \geq V_{\text {aut }}(Q+b)
$$

Therefore, in the states with low output $Y_{i}$, we have $b \leq d\left(Y_{i}\right)$, i.e., there are no capital inflows for these states.

Capital outflows in bad times provide good incentives because they occur only at output realizations so low that they are more likely to occur when borrower has undertaken too little investment. Their role is to provide incentives for the borrower is to invest enough to make it unlikely that those low-output states will occur.

\section{Home Bias through Portfolio Diversification}

With no information asymmetry, the home bias in equity portfolio depends crucially on the degree of market completeness. ${ }^{13}$ Despite of the increased cross-border financial transactions, international portfolios remain heavily tilted toward domestic assets. ${ }^{14}$ The literature on international portfolio emphasizes the link between home equity bias and home consumption bias (Obstfeld and Rogoff [33], Coeurdacier [12], Obstfeld [32], Engel and Matsumoto $[17])$.

Coeurdacier [12] characterizes the constant equity portfolio that reproduces the locally complete market allocation through trades in claims to domestic and foreign equities. The structure of these optimal portfolios reflects the hedging properties of relative equity returns against real exchange rate fluctuations. With CRRA preferences, the optimal equity

\footnotetext{
${ }^{13}$ The benchmark model without home bias in equity portfolio is in Helpman and Razin (1978).

${ }^{14}$ See French and Poterba (1991), Tesar and Werner (1995), and Ahearne, Griever and Warnock (2004).
} 
position is related to the covariance between the excess return on domestic equity (relative to foreign equity), and the rate of change of the real exchange rate. When the CRRA coefficient exceeds unity, home equity bias arises when excess domestic equity returns are positively correlated with an appreciation of the real exchange rate. In that case, efficient risk sharing requires that domestic consumption expenditures increase as the real exchange rate appreciates. If domestic equity returns are high precisely at that time, domestic equity provides the appropriate hedge against real exchange rate risk, and investors will tilt their portfolio towards domestic equity.

Coeurdacier and Gourinchas [13] introduce an additional source of risk, so that optimal portfolio allocation will typically require simultaneous holdings of equities and bonds. As relative bond returns are strongly positively correlated with the real exchange rate, it is optimal for investors to use bond positions to hedge real exchange rate risks while equities are left to hedge the impact of additional sources of risk on investors' total wealth. This is consistent the empirical finding that correlation between excess equity returns and the real exchange rate is too low to explain observed equity home bias (van Wincoop and Warnock [41]).

Furthermore, they show that home equity bias arises if the correlation between the return on non-financial wealth and the return on equity, conditional on bond returns, is negative (a generalization of both Baxter and Jermann [8], and Heathcote and Perri [22]).The reason is that an increase in domestic equity holdings increases its implicit domestic currency exposure. Investors optimally undo this exposure by shorting the domestic currency bond. The overall domestic bond position reflects the balance of these two effects, so it is possible for a country to have short or long domestic currency debt positions. This is in line with recent empirical evidence (Lane and Shambaugh [28] and Lane and Shambaugh [29]) that suggests large heterogeneity across countries in the currency denomination of external bond holdings. On average, advanced countries hold long (but small) domestic currency debt positions but some large countries, most notably the US, are short in their own currency debt. 


\subsection{Coeurdacier and Gourinchas (2009) model}

Consider a two-period endowment economy model. There are two symmetric countries, Home $(H)$ and Foreign $(F)$, each with a representative household. Each country specializes in the production of one tradable good. Agents consume both goods with a preference towards the local good. In period zero, no output is produced and no consumption takes place, but agents trade financial claims. In period one, country $i$ receives an exogenous endowment $y_{i}$ of good $i$. Countries are symmetric and $E_{0}\left(y_{i}\right)=1$ for both countries, where $E_{0}$ is the conditional expectations' operator, given date $t=0$ information. Once stochastic endowments are realized at period 1, households consume using the revenues from their portfolio chosen in period 0 and their endowment received in period 1 . Country $i$ household has the standard CRRA preferences.

The Home terms of trade, the relative price of the Home tradable good in terms of the Foreign tradable good, is denoted by $q \equiv p_{H} / p_{F}$. Trade in stocks and bonds occurs in period 0 . In each country there is one Lucas-style stock, a share $\delta$ of the endowment in country $i$ is distributed to stockholders as dividend, while a share $(1-\delta)$ is not capitalizable (labor income) and is distributed to households of country $i$. The supply of each type of share is normalized at unity. Agents can trade a bond in each country denominated in the composite good of country $i$. Buying one unit of the Home (Foreign) bond in period 0 gives one unit of the Home composite (Foreign) good at $t=1$. Both bonds are in zero net supply. Initially, each household fully owns the local stock equity, and has zero initial foreign assets.

Denote a country's holdings of local stock by $S$, and its holdings of bonds denominated in its local composite good by $b$. The vector $(S ; b)$ thus describes international portfolios. Symmetry of preferences and distributions of shocks implies that equilibrium portfolios are symmetric. $S>1 / 2$ means that there is equity home bias on stocks, while $b<0$ means that a country issues bonds denominated in its local good, and simultaneously lends in units of the foreign good. The equilibrium equity portfolio position (in the symmetric steady-state where $y=1$ and $b=0$ ) is given by

$$
S^{*}=\frac{1}{2}\left(\frac{2 \delta-1}{\delta}+\frac{(1-1 / \sigma)(2 a-1)}{\delta(1-\lambda)}\right)
$$

where $\lambda \equiv \phi\left(1-(2 a-1)^{2}\right)+(2 a-1)^{2} / \sigma$ represents the equilibrium terms of trade 
elasticity of relative output.

When $\delta<1$, the optimal equity portfolio has two components. The first term inside the brackets represents the position of a log-investor $(\sigma=1)$. The domestic investor is already endowed with an implicit equity position equal to $(1-\delta) / \delta$ through non-financial income. Offsetting this implicit equity holding and diversifying optimally implies a position $S=(2 \delta-1) / 2 \delta<1 / 2$ for $\delta<1$. The second component of the optimal equity portfolio represents a hedge against real exchange rate fluctuations. It only applies when $\sigma \neq 1$, i.e., when total consumption expenditures fluctuate with the real exchange rate. This hedging demand is a complex and non-linear function of the structure of preferences summarized by the parameters $\sigma, \phi$ and $a$. For reasonable parameter values, this hedging demand can contribute to home equity bias only when $\lambda<1$, i.e. when the terms of trade impact of relative supply shocks is large. Also, this hedge component can be rewritten as a function of the covariance-variance ratio between excess equity returns and the real exchange rate.

Now consider the set-up with bonds and additional independent risk factor $\widehat{\varepsilon}$. The model can be summarized by the (log-linearized) intertemporal allocation across goods and budget constraint. Relative returns on equities $\left(\widehat{R}_{e}\right)$, non-financial wealth $\left(\widehat{R}_{n}\right)$ and bonds $\left(\widehat{R}_{b}\right)$ are represented by

$$
\begin{aligned}
\widehat{R}_{e} & =\widehat{q}+\widehat{y}+\gamma_{e}^{\prime} \widehat{\varepsilon} \\
\widehat{R}_{b} & =(2 a-1) \widehat{q}+\widehat{y}+\gamma_{b}^{\prime} \widehat{\varepsilon} \\
\widehat{R}_{n} & =\widehat{q}+\widehat{y}+\gamma_{n}^{\prime} \widehat{\varepsilon}
\end{aligned}
$$

The solution for optimal portfolio is given by

$$
\begin{aligned}
S^{*} & =\frac{1}{2}\left(1-\frac{1-\delta}{\delta} \beta_{n, e}+\frac{(1-1 / \sigma)}{\delta} \beta_{R E R, b}\right) \\
b^{*} & =\frac{1}{2}\left(1-\frac{1-\delta}{\delta} \beta_{n, e}+\frac{(1-1 / \sigma)}{\delta} \beta_{R E R, b}\right),
\end{aligned}
$$

where $\beta_{.,}$are asset returns loadings on the real exchange rate and on non-financial income such that

$$
\begin{aligned}
\widehat{R E R} & =\beta_{R E R, b} \widehat{R}_{b}+\beta_{R E R, e} \widehat{R}_{e} \\
\widehat{R_{n}} & =\beta_{n, b} \widehat{R}_{b}+\beta_{n, e} \widehat{R}_{e} .
\end{aligned}
$$


The intuition is that the equilibrium bond and equity positions will hedge optimally the components of real exchange rate and non-financial income fluctuations with which they are correlated. Because bond returns offer a better hedge against real exchange rate risk than equities, holdings of equities take care of the exposure to other sources of risk, conditional on bond returns. Home equity bias will arise when $\operatorname{Cov}\left(R_{e}, R_{n} / R_{b}\right)<0$.

\section{Conclusion}

In an integrated world capital market with perfect information, all forms of capital flows are indistinguishable. Information frictions and incomplete risk sharing are important elements that needed to differentiate between equity and debt flows, and between different types of equities.

With information asymmetry between foreign and domestic investors, a country which finances its domestic investment through foreign debt or foreign equity portfolio issue, will inadequately augment its capital stock. Foreign direct investment flows, however, have the potential of generating an efficient level of domestic investment.

In the presence of asymmetric information between sellers and buyers in the capital market, foreign direct investment is associated with higher liquidation costs due to the adverse selection. Thus, the exposure to liquidity shocks determines the volume of foreign direct investment flows relative to portfolio investment flows. In particular, the informationliquidity trade-off helps explain the composition of equity flows between developed and emerging countries, as well as the patterns of FDI flows during financial crises.

The asymmetric information between domestic investors (as borrowers) and foreign investors (as lenders) with respect to investment allocation leads to moral hazard and thus generate an inadequate amount of borrowings. The moral hazard problem, coupled with limited enforcement, can explain why countries experience debt outflows in low income periods; in contrast to the predictions of the complete-market paradigm.

Finally, we analyze a risk-diversification model, where bond holdings hedge real exchange rate risks, while equities hedge non-financial income fluctuations. An equity home bias emerges as a calibratable equilibrium outcome. 


\section{References}

[1] V. Acharya, H. Shin, and T. Yorulmazer. Fire-sale FDI. Working Paper (2007).

[2] M. Aguiar and G. Gopinath. Fire-Sale Foreign Direct Investment and Liquidity Crises. The Review of Economics and Statistics 87(3), 439-52 (2005).

[3] R. Albuquerque. The composition of international capital flows: risk sharing through foreign direct investment. Journal of International Economics 61(2), 353-383 (2003).

[4] R. Albuquerque, N. Loayza, and L. Serven. World market integration through the lens of foreign direct investors. Journal of International Economics 66(2), 267-295 (2005).

[5] F. Allen and D. Gale. Limited Market Participation and Volatility of Asset Prices. The American Economic Review 84(4), 933-955 (1994).

[6] A. Atkeson. International lending with moral hazard and risk of repudiation. Econometrica 59(4), 1069-1089 (1991).

[7] M. Baker, C. Foley, And J. Wurgler. Multinationals as arbitrageurs: The effect of stock market valuations on foreign direct investment. Review of Financial Studies (2008).

[8] M. Baxter and U. Jermann. The international diversification puzzle is worse than you think. The American Economic Review 87(1), 170-180 (1997).

[9] R. Caballero and A. Krishnamurthy. International and domestic collateral constraints in a model of emerging market crises. Journal of Monetary Economics 48(3) (2001).

[10] R. Chang and A. Velasco. A Model of Financial Crises in Emerging Markets. Quarterly Journal of Economics 116(2) (2001).

[11] S. Claessens, M. Dooley, and A. Warner. Portfolio capital flows: hot or cold? The World Bank Economic Review 9(1), 153 (1995). 
[12] N. Coeurdacier. Do trade costs in goods market lead to home bias in equities? Journal of International Economics 77(1), 86-100 (2009).

[13] N. Coeurdacier and P. Gourinchas. When Bonds Matter: Home Bias in Goods and Assets. NBER working paper (2009).

[14] D. Diamond and P. Dybvig. Bank Runs, Deposit Insurance, and Liquidity. The Journal of Political Economy 91(3), 401-419 (1983).

[15] D. Diamond and R. Rajan. Banks, short-term debt and financial crises: theory, policy implications and applications. Carnegie-Rochester Confer. Series on Public Policy 54(1), 37-71 (2001).

[16] J. Eaton and M. Gersovitz. Debt with potential repudiation: Theoretical and empirical analysis. The Review of Economic Studies 48(2), 289-309 (1981).

[17] C. Engel and A. Matsumoto. International Risk Sharing: Through Equities or Bonds? NBER working paper (2008).

[18] K. Froot And J. Stein. Exchange rates and foreign direct investment: an imperfect capital markets approach. The Quarterly Journal of Economics 106(4), 1191-1217 (1991).

[19] I. Goldstein and A. Razin. An information-based trade off between foreign direct investment and foreign portfolio investment. Journal of International Economics 70(1), $271-295$ (2006).

[20] I. Goldstein, A. Razin, And H. Tong. Liquidity, Institutional Quality and the Composition of International Equity Outflows. NBER Working Paper (2008).

[21] R. Gordon and A. Bovenberg. Why is capital so immobile internationally? Possible explanations and implications for capital income taxation. The American Economic Review 86(5), 1057-1075 (1996).

[22] J. Heathcote and F. Perri. The International Diversification Puzzle Is Not As Bad As You Think. NBER working paper (2007). 
[23] K. Kirabaeva. International Capital Flows and Liquidity Crises. Working Paper (2009).

[24] M. Klein, J. Peek, And E. Rosengren. Troubled banks, impaired foreign direct investment: the role of relative access to credit. American Economic Review 92(3), 664-682 (2002).

[25] M. Klein and E. Rosengren. The real exchange rate and foreign direct investment in the United States: relative wealth vs. relative wage effects. Journal of International Economics 36(3-4), 373-389 (1994).

[26] M. Kose, E. Prasad, K. Rogoff, and S. Wei. Financial Globalization: A Reappraisal. NBER working paper (2006).

[27] P. Krugman. Fire-Sale FDI. Capital Flows and the Emerging Economies: Theory, Evidence and Controversies, Chicago pp. 43-60 (2000).

[28] P. Lane and J. Shambaugh. Financial Exchange Rates and International Currency Exposures. NBER Working Paper (2007).

[29] P. Lane and J. Shambaugh. The Long or Short of it: Determinants of Foreign Currency Exposure in External Balance Sheets. NBER Working Paper (2009).

[30] P. Loungani, A. Mody, And A. Razin. The global disconnect: the role of transactional distance and scale economies in gravity equations. Scottish Journal of Political Economy 49, 526-543 (2002).

[31] R. McKinnon And H. Pill. Credible liberalizations and international capital flows: the overborrowing syndrome. Financial deregulation and integration in East Asia $\mathbf{7}$, $42(1996)$.

[32] M. Obstfeld. International Risk Sharing and the Costs of Trade. NBER working paper (2009).

[33] M. Obstfald and K. Rogoff. The Six Major Puzzles in International Macroeconomics: Is There a Common Cause? NBER Working Paper (2000). 
[34] R. Portes, H. Rey, And Y. OH. Information and capital flows: The determinants of transactions in financial assets. European Economic Review 45(4-6), 783-796 (2001).

[35] A. RAZIn And E. SAdkA. Gains from FDI inflows with incomplete information. Economics Letters 78(1), 71-77 (2003).

[36] A. Razin, E. SAdkA, And C. Yuen. Implications of the home bias: a pecking order of capital inflows and corrective taxation. The economics of globalization: policy perspectives from public economics p. 85 (1999).

[37] D. Rodrik and A. Velasco. Short-term capital flows. NBER working paper (1999).

[38] S. Rossi And P. Volpin. Cross-country determinants of mergers and acquisitions. Journal of Financial Economics 74(2), 277-304 (2004).

[39] H. Tong and S. Wei. The Composition Matters: Capital Inflows and Liquidity Crunch during a Global Economic Crisis. NBER working paper (2009).

[40] V. Tsyrennikov. Capital Outflows And Moral Hazard. Working Papers (2007).

[41] E. van Wincoop and F. Warnock. Is Home Bias in Assets Related to Home Bias in Goods? NBER Working Papers (2006).

[42] S. WEI. Connecting two views on financial globalization: Can we make further progress? Journal of The Japanese and International Economies 20(4), 459-481 (2006). 